\title{
Chromatographic Determination of Riboflavin in the Presence of Tetracyclines in Skimmed and Full Cream Milk using Fluorescence Detection
}

\author{
Luiz Severo Silva Jr. ${ }^{\S, a}$, Marcello G. Trevisan ${ }^{b}$, Susanne Rath ${ }^{b}$, Ronei J. Poppi ${ }^{b}$ \\ and Felix G. R. Reyes ${ }^{*, a}$ \\ ${ }^{a}$ Faculdade de Engenharia de Alimentos, Universidade Estadual de Campinas, CP 6121, \\ 13081-970 Campinas - SP, Brazil \\ ${ }^{b}$ Instituto de Química, Universidade Estadual de Campinas, CP 6154, 13083-970 Campinas - SP, Brazil
}

\begin{abstract}
Foi estabelecido um método cromatográfico rápido e simples para a determinação de riboflavina em leite bovino, na presença de tetraciclinas. Para tanto, as proteínas foram precipitadas com ácido tricloroacético e a separação realizada por CLAE em fase reversa com detector de fluorescência. Foi utilizada uma coluna $\mathrm{C}_{8}$ com eluição isocrática e fase móvel acetato de sódio $0,1 \mathrm{~mol} \mathrm{~L}^{-1}$, cloreto de cálcio $35 \mathrm{mmol} \mathrm{L}^{-1}$, EDTA $25 \mathrm{mmol} \mathrm{L}^{-1}$ : metanol $(65: 35 \mathrm{v} / \mathrm{v})$. O método foi validado mediante avaliação dos seguintes parâmetros: linearidade $(0,9980)$, faixa linear $(0,50$ a $1,30 \mu \mathrm{g}$ $\mathrm{mL}^{-1}$ ), precisão intra e inter-ensaio (RSD $\leq 0,5 \%$ ), exatidão (recuperação $92 \%$ ) e limites de detecção e de quantificação $\left(0,75 \mu \mathrm{g} \mathrm{mL}^{-1}\right.$ e $0,22 \mu \mathrm{g} \mathrm{mL} \mathrm{m}^{-1}$, respectivamente). O método foi aplicado na análise de leite integral e desnatado, mostrando-se robusto na presença de substâncias fluorescentes como as tetraciclinas, e quando comparado com o método espectrofluorimétrico, não revelou diferença significativa $(\mathrm{p} \leq 0,05)$ entre os resultados obtidos.
\end{abstract}

An easy and simple chromatographic method for the determination of riboflavin in bovine milk in the presence of tetracyclines was established. For this, the proteins were precipitated with trichloroacetic acid and the separation was carried out by reversed-phase HPLC with fluorescence detection. $\mathrm{A}_{8}$ column was used with isocratic flow using a mobile phase consisting of $0.1 \mathrm{~mol}$ $\mathrm{L}^{-1}$ sodium acetate, $35 \mathrm{mmol} \mathrm{L}{ }^{-1}$ calcium chloride and $25 \mathrm{mmol} \mathrm{L}^{-1}$ EDTA : methanol (65:35 v/v). The method was validated by means of the following parameters: linearity (0.9980), linear range $\left(0.50-1.30 \mu \mathrm{g} \mathrm{mL}^{-1}\right)$, intra- and inter-assay precision (RSD $\left.\leq 0.5 \%\right)$, accuracy (recovery $\left.92 \%\right)$, and detection and quantitation limits $\left(0.75 \mu \mathrm{g} \mathrm{mL}^{-1}\right.$ and $0.22 \mu \mathrm{g} \mathrm{mL}^{-1}$, respectively). The method was applied for analysis of full cream and skimmed milk, showing robustness in the presence of tetracyclines, and when compared with a spectrofluorimetric method showed no significant difference $(\mathrm{p} \leq 0.05)$ between the results obtained.

Keywords: riboflavin, milk, tetracyclines

\section{Introduction}

Riboflavin is an important vitamin of the B complex (vitamin $\mathrm{B}_{2}$ ) acting as an intermediary in the transfer of electrons in biological redox reactions and having an important function in cell growth. As with all vitamins of the B complex, riboflavin is only synthesized by microorganisms and higher vegetables, not by animals, which must obtain it from their food. Considering the high concentrations of B complex vitamins present in meat and

\footnotetext{
* e-mail: reyesfgr@fea.unicamp.br

§ Present Address: Universidade do Oeste de Santa Catarina, Campus Videira, Rua Paese 198, 89560-000, Videira - SC, Brazil.
}

milk, these foods are the best natural sources of riboflavin in the human diet in the western world. ${ }^{1}$

Riboflavin is stable during heat processing, such as pasteurization, evaporation or condensation, which have little effect on the variation in riboflavin present in dairy products. However, considerable loss may occur due to photodegration from exposure of food to light. Another important loss of riboflavin occurs due to its water soluble profile and it is found in juices, whey and cooking waters. ${ }^{1,2}$ Thus, it is interesting not only to monitor the riboflavin concentration in dairy products but also to study the influence of manufacturing and storage processes on its variation. In addition, studies ${ }^{2-5}$ have shown that alterations in some of 
the organoleptic features of bovine milk and other liquids, like wine and beverages, have a correlation with riboflavin photodegration, which induces the degradation of sulfurcontaining compounds by photochemical sensitization. In these cases, the loss of riboflavin can be used as a natural indicator for the degradation parameters, such as source and intensity of light, manipulation forms, heat treatment and storage time. Thus the determination of riboflavin is necessary, either from the nutritional point of view or to quantify parameters in several dairy foods and beverages.<smiles>Cc1cc2nc3c(=O)[nH]c(=O)nc-3n(CC(O)C(O)C(O)CO)c2cc1C</smiles>

Figure 1. Chemical structure of riboflavin.

The standard method for total riboflavin determination in food is the AOAC fluorimetric method, ${ }^{6}$ since riboflavin has a fluorescence group, as shown in Figure 1. This involves a difficult and tedious procedure, including sample acidification and autoclaving. Furthermore, the proteins are removed by numerous $\mathrm{pH}$ adjustments, filtration steps and oxidation to remove fluorescent interferents. Thus several methods for the determination of only riboflavin alone in foods, ${ }^{7,8}$ wine, ${ }^{3}$ milk ${ }^{9-11}$ and baker's yeast ${ }^{12}$ or riboflavin in association with other vitamins of the $\mathrm{B}$ complex in foods, ${ }^{13,14}$ royal jelly ${ }^{15}$ and mushrooms ${ }^{16}$ have been developed.

Tetracyclines is a common name for a group of antimicrobials used to prevent or treat mastitis in cows, resulting in residues in the milk. ${ }^{17,18}$ These antimicrobials can increase their natural fluorescence under alkaline conditions or by forming a fluorescent metal chelate with calcium ions. ${ }^{19}$ The tetracyclines have fluorescence in the excitation range of 310 to $420 \mathrm{~nm}$ and emission of 420 to $590 \mathrm{~nm}$, while riboflavin fluoresces in 325 to $405 \mathrm{~nm}$ (excitation) and 320 to $590 \mathrm{~nm}$ (emission). ${ }^{20}$ Otherwise, there is no fluorimetric method able to quantify the riboflavin in the presence of tetracycline. In this way, the presence of tetracyclines may interfere in the chromatographic analysis of riboflavin in milk using a fluorescence detector. ${ }^{21}$
In this work we present a method for the determination of riboflavin in milk, in the presence of tetracyclines (oxytetracycline (OTC), doxycycline (DC) and tetracycline (TC)), using a simple procedure for the extraction of the milk proteins together with the direct conversion of the riboflavin co-enzyme forms, such as flavin mononucleotide (FMN) and flavin adenine dinucleotide (FAD) into free riboflavin. Using this procedure, the total riboflavin was quantified in different samples of full cream and skimmed Brazilian bovine milk. The proposed method was also compared with a spectrofluorimetric method. ${ }^{22}$

\section{Experimental}

\section{Apparatus}

The chromatographic analysis was performed using a Waters 406 chromatograph, equipped with an isocratic pump, Rheodyne injector, with a sample loop of $20 \mu \mathrm{L}$, a Shimadzu riboflavin-10A fluorescence detector, and a Chromjet integrator. The chromatographic separation was carried out using a $\mathrm{C}_{8}$ analytical column (250 mm x 4.6 $\mathrm{mm}, 5 \mu \mathrm{m})$ (Varian) and $\mathrm{a}_{8}$ guard column $(7.5 \mathrm{~mm} \times 6$ $\mathrm{mm}, 5 \mu \mathrm{m})$ (Alltech). The fluorescence parameters were adjusted using excitation at $420 \mathrm{~nm}$ and emission at 530 nm. A Fanem centrifuge model 204-NR, was used during the extraction procedure. In the spectrofluorimetric analysis, a Perkin-Elmer LS 55 Luminescence Spectrometer with a $10 \mathrm{~mm}$ quartz cuvette, was used at $23 \pm 1^{\circ} \mathrm{C}$.

\section{Reagents and solutions}

The reagents used were at least of analytical grade, as follows: sodium acetate (Merck), calcium chloride (Reagen), EDTA (Reagen) and trichloroacetic acid (Baker). Riboflavin (98\%, purity) was purchased from Sigma, and methanol (Mallinckrodt) was HPLC grade.

All solutions were prepared with deionized water obtained from a Millipore Milli-Q Académic System. The mobile phase consisted of an aqueous solution of sodium acetate $\left(0.10 \mathrm{~mol} \mathrm{~L}^{-1}\right)$, calcium chloride $\left(35.0 \mathrm{mmol} \mathrm{L}^{-1}\right)$ and EDTA (25.0 mmol L-1):methanol (65:35 v/v), filtered through $0.45 \mu \mathrm{m}$ cellulose membrane filters (Millipore). A standard stock solution of $100 \mu \mathrm{g} \mathrm{mL}^{-1}$ riboflavin was prepared according to the AOAC procedure, ${ }^{6}$ where 50.0 $\mathrm{mg}$ riboflavin was dissolved in $0.02 \mathrm{~mol} \mathrm{~L}^{-1}$ acetic acid and the volume made up to $500 \mathrm{~mL}$, with the same solvent. The stock solution was stored in amber glass bottles in the dark, under refrigeration at $4{ }^{\circ} \mathrm{C}$, for a maximum period of 2 weeks. 


\section{Samples}

Nine different commercial brands of Ultra High Temperature (UHT) Brazilian milk were analyzed: five were skimmed milk and four were full cream milk. All samples were purchased from local markets in Campinas-SP, Brazil.

\section{Sample analysis}

For milk protein extraction ${ }^{17} 1.00 \mathrm{~mL}$ of milk sample was added to an Eppendorf tube, followed by $1.50 \mathrm{~mL}$ of $30 \%(\mathrm{v} / \mathrm{v})$ trichloroacetic acid (TCA). The tube was mixed and centrifuged for 10 minutes at $2500 \mathrm{~g}$ force. The supernatant solution was filtered through a $0.45 \mu \mathrm{m}$ membrane and $20 \mu \mathrm{L}$ was injected into the chromatographic system, with an isocratic flow of $1.0 \mathrm{~mL} \mathrm{~min}^{-1}$. The HPLC analysis was carried out in triplicate.

\section{Results and Discussion}

\section{Sample preparation}

The extraction technique suggested by Furusawa ${ }^{17}$ was used with some modification, such as a higher concentration of TCA. The addition of TCA to the milk promotes an immediate precipitation of the milk proteins, producing a clear supernatant. Furthermore, TCA causes a direct acid hydrolysis of the riboflavin co-enzyme forms, such as flavin mononucleotide (FMN) and flavin adenine dinucleotide (FAD), into free riboflavin, which is determined in the form of total riboflavin by HPLC with fluorescence detector. This procedure works without any complex extraction or cleanup procedure such as oxidation ${ }^{6}$ which may decrease the riboflavin concentration in the sample by, approximately, $15 \%$ due to oxidative destruction. ${ }^{23}$ It is advantageous due to the ease and rapidity in determining total riboflavin in milk samples. The time necessary for sample preparation was 12 minutes, considering the centrifugation time.

\section{HPLC conditions}

The HPLC conditions were optimized in order to allow the separation of all compounds under study. The optimized mobile phase consisted of an aqueous solution-methanol $(65: 35 \mathrm{v} / \mathrm{v})$, as described before. The method has the advantage of being able to determine riboflavin in the presence of tetracyclines in milk, using a simple procedure of extraction and clean-up of the sample. Figure 2 shows the chromatograms of riboflavin standard and a sample of milk, obtained under the optimized chromatographic conditions. The milk extract did not present interferents, as can be verified in the chromatogram of the milk sample (Figure 2b). The total time for the chromatographic analysis was 7 minutes.

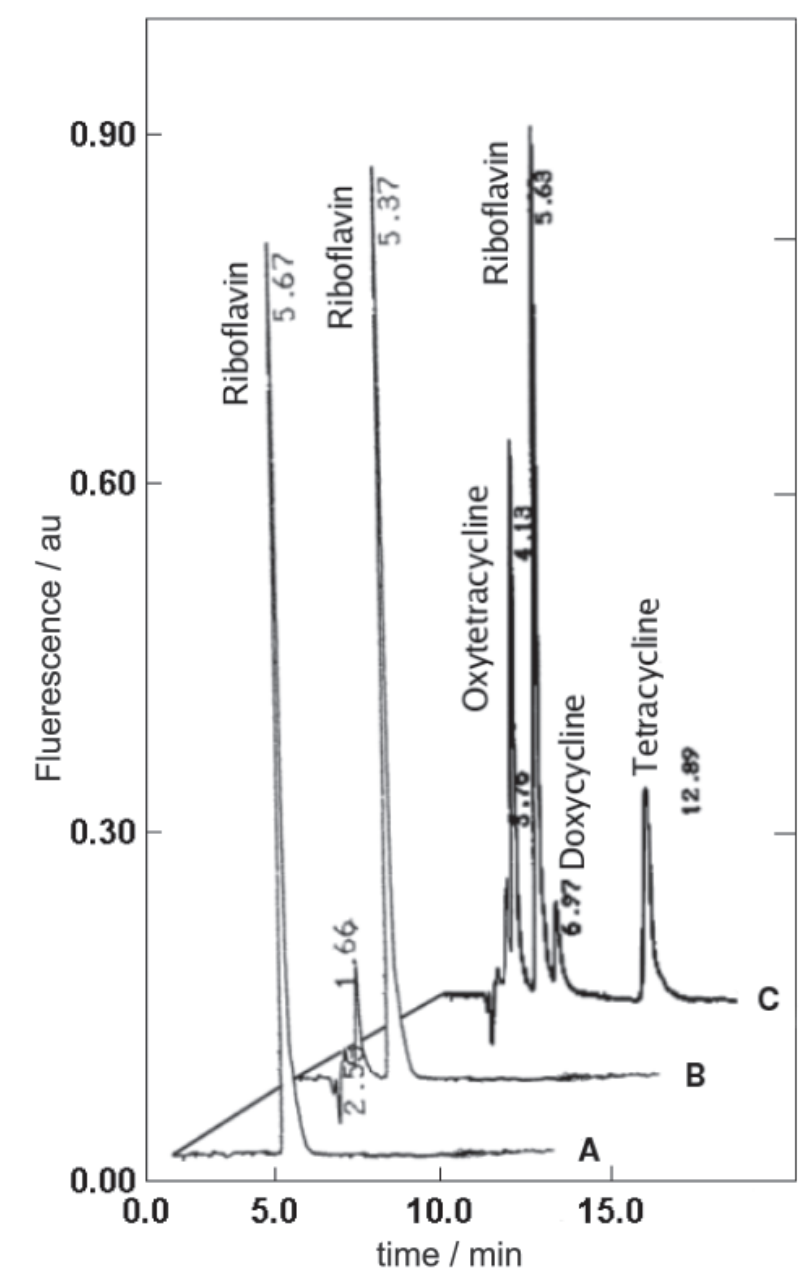

Figure 2. Chromatograms of (A) standard of riboflavin; (B) milk sample; and $(\mathbf{C})$ riboflavin in milk in the presence of oxytetracycline (OTC), doxycycline (DC) and tetracycline (TC).

\section{Validation}

The HPLC method was validated in the presence of tetracyclines, by evaluation of the following parameters: linearity, linear range, intra and inter-assay precision, accuracy detection and quantitation limit and recovery.

The analytical curve was obtained with six concentrations of the riboflavin standard solution ( 0.51 to $\left.1.33 \mu \mathrm{g} \mathrm{mL} \mathrm{m}^{-1}\right)$. The linear regression parameters were obtained by plotting peak area against riboflavin concentration, showing linearity in this range. The sensitivity was calculated as $9.5310^{5}$ arbitrary units $\mathrm{mL} \mu \mathrm{g}^{-1}$ and the linearity, expressed as the regression coefficient, was 0.9980 .

The quantitation limit (LOQ) was determined through the following expression $\mathrm{LOQ}=10 \mathrm{~s}_{\mathrm{y} / \mathrm{x}} / \mathrm{m}$, where $\mathrm{s}_{\mathrm{y} / \mathrm{x}}$ is the 
estimate of the standard deviation of the regression line and " $\mathrm{m}$ " the sensitivity (angular coefficient of the regression line). For the detection limit (LOD) a value of 3 was employed in the expression above.

The accuracy of the method was evaluated based on the recovery of known amounts of riboflavin spiked in milk samples, with duplicate analysis. For the recovery test, the milk samples were fortified with $50 \% \mathrm{v} / \mathrm{v}$ of a solution 1.12 $\mathrm{mL}^{-1}$ of riboflavin. The spiked samples were mixed for 5 hours in the dark, submitted to the extraction process and the riboflavin concentration obtained compared with blank samples. The analytical parameters evaluated are shown in Table 1.

Table 1. Analytical parameters for the determination of riboflavin in milk

\begin{tabular}{ll}
\hline Analytical Parameters & Result \\
\hline Limit of detection $\left(\mu \mathrm{g} \mathrm{mL}^{-1}\right)$ & 0.22 \\
Limit of quantitation $\left(\mu \mathrm{g} \mathrm{mL}^{-1}\right)$ & 0.75 \\
Linearity $\left(\mathrm{r}^{2}\right)$ & 0.9980 \\
Precision $(\%)$ & \\
Intra-assay $\left(\mathrm{c}=0.714 \mu \mathrm{g} \mathrm{mL}^{-1}\right)$ & 0.5 \\
Inter-assay $\left(\mathrm{c}_{2}=0.714 \mu \mathrm{g} \mathrm{mL}^{-1}\right)$ & 0.5 \\
$\qquad\left(\mathrm{c}_{3}=0.918 \mu \mathrm{g} \mathrm{mL}^{-1}\right)$ & 0.3 \\
$\quad\left(\mathrm{c}_{4}=1.122 \mu \mathrm{g} \mathrm{mL}^{-1}\right)$ & 0.2 \\
Recovery $(\%)$ & 92 \\
\hline
\end{tabular}

The precision of the method was evaluated by determination of the intra- and inter-assay precision. The intra-assay precision was determined by the evaluation of the RSD of 10 consecutive determinations, at a riboflavin concentration of $0.714 \mu \mathrm{g} \mathrm{mL}^{-1}$. A RSD value lower than $0.5 \%$ was obtained. The inter-assay precision was evaluated by means of analysis of solutions containing $0.714,0.918$ and $1.122 \mu \mathrm{g} \mathrm{mL}^{-1}$ of riboflavin on five consecutive days. All the determinations were carried out in triplicate and the RSD values varied from 0.2 to $0.5 \%$.

\section{Riboflavin determination in milk}

The samples were analyzed using the optimized conditions of the experimental procedure, and the results obtained are summarized in Table 2. The common range of total riboflavin concentration in milk ${ }^{24}$ varies from 1.50 to $1.80 \mu \mathrm{g} \mathrm{mL}^{-1}$. As can be verified, all the results obtained were within the range from 1.49 to $1.89 \mu \mathrm{g} \mathrm{mL}^{-1}$, which indicate the samples analyzed were in the acceptable range for riboflavin.

\section{Comparison of the HPLC with a spectrofluorimetric method}

The results obtained for milk samples by the HPLC method were compared with those obtained applying the spectrofluorimetric method, using a Perkin-Elmer LS 55 spectrofluorimeter and a standard addition method to perform the riboflavin determination. ${ }^{22}$ The same extracts of the milk samples were analyzed by the two methods and statistical analysis using the Student $t$-test showed no significant difference $(\mathrm{p} \leq 0.05)$ between the results obtained by the two methods. The results are presented in Table 2.

Table 2. Results for the determination of riboflavin in milk (average $\left.\pm \mathrm{s}^{*}\right)$

\begin{tabular}{lcc}
\hline Samples & \multicolumn{2}{c}{ Riboflavin $\left(\mu \mathrm{g} \mathrm{mL}^{-1}\right)$} \\
\cline { 2 - 3 } & HPLC & Fluorimetric Method \\
\hline Full cream sample 1 & $1.59 \pm 0.03$ & $1.56 \pm 0.08$ \\
Full cream sample 2 & $1.54 \pm 0.02$ & $1.61 \pm 0.04$ \\
Full cream sample 3 & $1.74 \pm 0.02$ & $1.82 \pm 0.25$ \\
Full cream sample 4 & $1.59 \pm 0.06$ & $1.69 \pm 0.06$ \\
Skimmed sample 1 & $1.89 \pm 0.02$ & $1.78 \pm 0.15$ \\
Skimmed sample 2 & $1.71 \pm 0.02$ & $1.64 \pm 0.05$ \\
Skimmed sample 3 & $1.77 \pm 0.02$ & $1.68 \pm 0.06$ \\
Skimmed sample 4 & $1.49 \pm 0.01$ & $1.46 \pm 0.09$ \\
Skimmed sample 5 & $1.71 \pm 0.02$ & $1.85 \pm 0.10$ \\
\hline *s: estimative of the absolute standard deviation $(\mathrm{n}=3)$.
\end{tabular}

\section{Interferences}

The interference of riboflavin in the determination of tetracyclines in milk was reported by Carson and Breslyn. ${ }^{21}$ Until now, there is no report on the determination of riboflavin in the presence of tetracyclines in skimmed and full cream milk. In this work, the determination of riboflavin was evaluated in the presence of three tetracyclines (OTC, DC and TC) by HPLC.

Brazilian legislation has established a maximum residue limit (MRL) of $100 \mu \mathrm{g} \mathrm{L}^{-1}$ for OTC and TC, alone or in combination. No MRL has been established for DC. The International Dairy Federation ${ }^{25}$ recommends the same limits. Thus, the milk samples were spiked with $100 \mu \mathrm{g} \mathrm{L}^{-1}$ of each tetracycline and analyzed by the proposed HPLC method. It was verified that none of the tetracyclines overlapped the riboflavin peak, allowing for riboflavin determination in their presence (Figure 2-C). In this way, the method was shown to be robust and specific for the determination of riboflavin in full cream and skimmed milk, even in the presence of the fluorescent tetracyclines.

\section{Conclusions}

The proposed method for the quantitative determination of riboflavin in full cream and skimmed milk offers some advantages, such as simplicity, rapidity and low cost. The proposed method presents accuracy and precision, as shown by the low standard deviation and correlation to a comparative method. Furthermore, the 
methodology proved to be selective and robust when samples spiked with tetracyclines were analyzed. Consequently, the method can be applied to quantify riboflavin in milk, being suitable for routine analysis.

\section{Acknowledgments}

The authors wish to thank the CNPq, FAPESP and FINEP/RECOPE for financial support. M. G. Trevisan and L. S. Silva Jr. are thankful to CNPq for their master's and doctorate fellowships, respectively.

\section{References}

1. Copperman, J. M.; Lopez, R. In Handbook of Vitamins; Machlin, L. J., ed.; $2^{\text {nd }}$ ed., Marcel Dekker, Inc.: New York, 1991.

2. Cataldi, T. R. I.; Nardiello, D.; Scrano, L.; Scopa, A.; J. Agric. Food Chem. 2002, 50, 6643.

3. Bassette, R.; Fung, D. Y. C.; Mantha, V. R.; CRC Crit. R. Food Sci. 1986, 24, 1.

4. Andres-Lacueva, C.; Mattivi, F.; Tonon, D.; J. Chromatogr. A 1998, 823, 355.

5. Varnam, A. H.; Sutherland, J. P.; Milk and Milk Products Technology, Chemistry and Microbiology, Chapman \& Hall: London, 1996, vol. 1.

6. AOAC Official Method 981.15, Official Methods of Analysis of AOAC International, $16^{\text {th }}$ ed., Section 45.1.09, Whashington, 1995.

7. Vinas, P.; Balsalobre, N.; Lopez-Erroz, C.; Hernandez-Cordoba, M.; J. Agric. Food Chem. 2004, 52, 1789.

8. Gliszczynska-Swiglo, A.; Koziolowa, A.; J. Chromatogr. A 2000, 881, 285.

9. Caelen, I.; Kalman, A.; Wahlstrom, L.; Anal. Chem. 2004, 76, 137.

10. Ashoor, S. H.; Knox, M. J.; Olsen, J. R.; Deger, D. A.; J. AOAC 1985, 68, 693.
11. Rashid, I.; Potts, D.; J. Food Sci. 1980, 45, 744.

12. Gliszczynska-Swiglo, A.; Koziolowa, A.; J. Chromatogr. A 1998, 822, 59.

13. Agostini, T. S.; Godoy, H. T.; J. High Resolut. Chromatogr. 1997, 20, 245.

14. Woollard, D. C.; Indyk, H. E.; J. AOAC Int. 2002, 85, 945.

15. Presoto, A. E. F.; Rios, M. D. G.; de Almeida-Muradian, L. B.; J. Braz. Chem. Soc. 2004, 15, 136.

16. Esteve, M. J.; Farre, R.; Frigola, A.; Garcia-Cantabella, J. M.; J. Agric. Food Chem. 2001, 49, 1450.

17. Furusawa, N.; J. Chromatogr. A 1999, 839, 247.

18. Severo Silva Jr., L.; Ph.D. Thesis, FEA - Universidade Estadual de Campinas, Brazil, 2004.

19. Iwaki, K.; Okumura, N.; Yamazaki, M.; J. Chromatogr. 1992, $623,153$.

20. Garcia, I.; Sarabia, L. A.; Ortiz, M. C.; Anal. Chim. Acta 2004, $501,193$.

21. Carson, M. C.; Breslyn, W.; J. AOAC Int. 1996, 79, 29.

22. Trevisan, M. G.; MSc. Dissertation, IQ - Universidade Estadual de Campinas, Brazil, 2003.

23. Woodrow, I. L.; Torrie, K. M.; Henderson, G. A.; Inst. Can. Technol. Aliment. 1969, 2, 120; in Rashid, I.; Potts, D.; J. Food Sci. 1980, 45, 744.

24. Hartman, A. M.; Dryden, L. P. In Vitamins in Milk and Milk Products in Fundamentals of Dairy Chemistry; Webb, B. H.; Johnson, A. H.; Alford, J. A., eds.; $2^{\text {nd }}$ ed., AVI: New York, 1983.

25. Honakanen-Buzalski, T.; Reybroeck, W. In Residues and Contaminants in Milk and Milk Products; International Dairy Federation ed.; IDF General Secretariat: Brussels, 1997.

Received: November 3, 2004 Published on the web: August 30, 2005

FAPESP helped in meeting the publication costs of this article. 